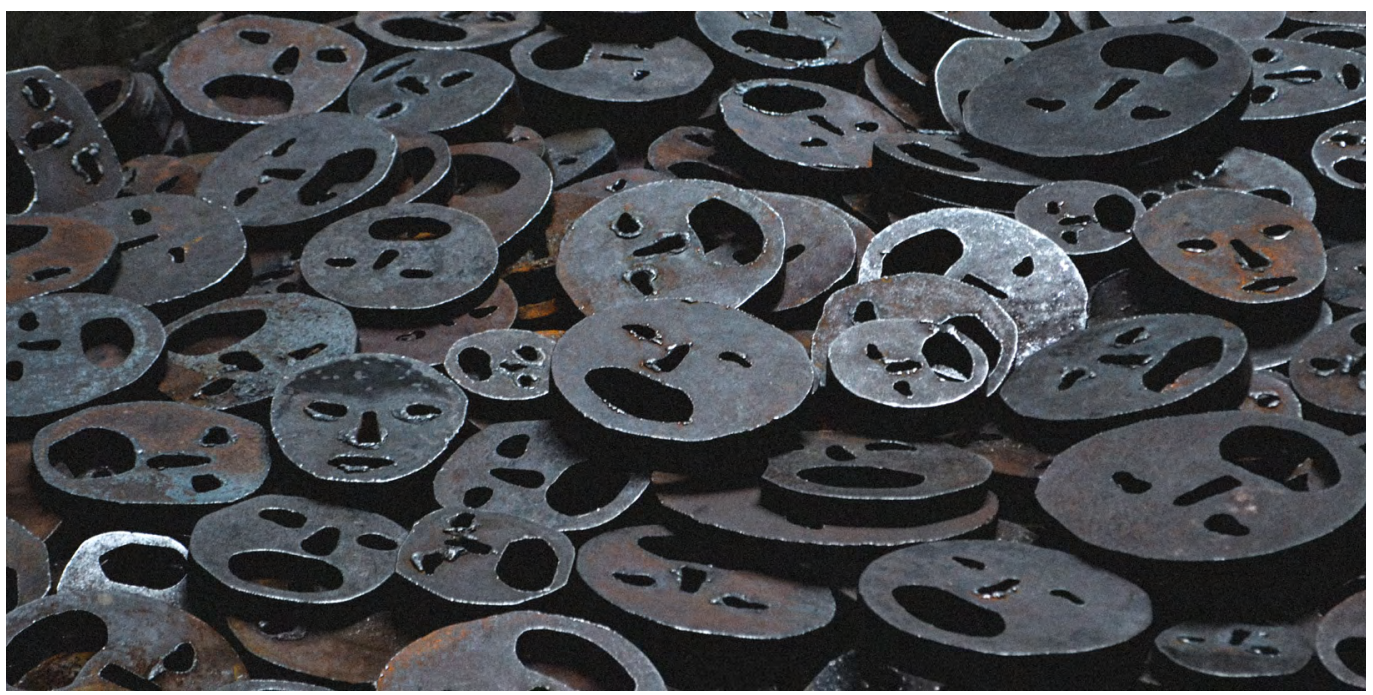

\section{(Self-)Censorship and Chinese Feminist \\ Networking in a Global Perspective}

WANG Zheng

$\mathrm{n}$ this essay, I will examine the relationship between the Chinese feminist movement and self-censorship in its temporal and spatial dimensions. Temporally, my analysis will take into account the period from 1989 up to the time of writing in July 2020. This temporal frame covers the Chinese political vicissitudes from the Tiananmen Square Incident of 1989 to the passage of the Hong Kong National Security Law in 2020-three decades that have also witnessed my conscious engagement in feminist activities in China and beyond. Regardless of whether or not individual feminists have paid attention to politics, every step of the contemporary Chinese feminist movement has been embedded in this political ecology and, for one reason or another, all people involved have
Faces. PC: (CC) Tyler Lowmiller. experienced some degree of self-censorship. Here, I will offer a brief summary of the political control and self-censorship in this particular period of Chinese history.

Although we all live in the same time frame, we are all situated in different spaces. There are differences between living at home and abroad; regional differences in China; differences between, in, and outside the official system; and differences among diverse social positions. Differences in geographical and social locations condition our experiences, concerns, and feminist actions and strategies in the same historical process. Therefore, my summary necessarily only expresses my experiences and concerns derived from my specific spatial locations over the years. 


\section{A Brief Review of Self- Censorship in My Personal Experience}

The Chinese Society for Women's Studies (海外中 华妇女学会, CSWS) was founded in the summer of 1989, right after the Chinese Communist Party (CCP) brutally suppressed the student movement in China. At that time, I was a PhD student at the University of California, Davis, and had returned to Beijing to participate in the student movement because of my passion for China's political reforms. Exactly because of that experience, I saw clearly that the space for promoting political reform in China was completely sealed off after 4 June and we overseas Chinese students had an obligation to organise meaningful political activities to continue the struggle that had been violently suppressed in China. In particular, through my close interaction with male prodemocracy activists in 1989, I realised that these supposed fighters for democracy were actually full of patriarchal ideas and deeply saturated in Chinese hierarchical power relations, with no capacity for self-reflection.

From my perspective as a $\mathrm{PhD}$ student researching the history of modern China, I saw no sign of progress among the young male intellectuals from the men in the early CCP in terms of their masculinist mindsets. It was clear to me that, at the end of the twentieth century, Chinese feminists should no longer regard male intellectuals as natural leaders, but instead should begin an independent feminist movement articulating critical feminist voices as a way to participate in China's political, social, and cultural transformations. At that time, I had not yet read the sharp criticism by the late Qing feminist He Yinzhen of her contemporary male elites, but from historical research and personal experience, I realised that eradicating China's patriarchal foundation would be critical to developing political democracy in China. In this sense, the founding of the CSWS, for me, was an opportunity to utilise my own spatial advantage to break domestic political constraints in China as well as to materialise my feminist vision of political transformation in the country.
This conscious rejection of political control changed, however, once the geographical scene changed. In 1993, the CSWS organised a two-week feminist workshop in collaboration with scholars at Tianjin Normal University. We imposed strong self-censorship on ourselves because we did not have a clear sense of how severe political taboos were in China after 4 June. I dared not directly comment on domestic issues, but only introduced the history of the American feminist movement and the core concepts of feminism and gender in a very circumspect way. However, in our exchanges with scholars and officials from the All-China Women's Federation (ACWF), we found there was actually a lot of room for discussion, especially in private settings. Those of us studying in the United States were the ones constrained by our overseas identities. We were afraid we would be labelled 'Western bourgeois feminists'. In fact, Chinese women researchers who participated in the workshop did not share our worries. Rather, they expressed great interest in the development of various feminist thought and theories in the world. This made me see that we could translate feminist works as a way to expand the space for feminist discourse in China. At the same time, I also began to reflect on my self-censorship and to consciously pay attention to the feasibility of breaking political taboos in different social spaces and on different fronts.

In my personal actions, I have consciously challenged taboos in two aspects. First, in a minor manner, I have been proudly labelling myself a 'feminist' (女权主义) in various public settings in China, staging individual performances to counter the mainstream discourse that stigmatises and demonises feminism. I was probably the first person to 'come out' as a feminist at a time when feminists in China generally called themselves 'women researchers' (妇女研究者) or 'women-work cadres' (妇女工作千部). Second, I collaborated with scholars in China to launch the development of women's and gender studies in Chinese higher education. In my view, colleges and universities could be institutional spaces in which to achieve breakthroughs - that is, for us to 
create feminist academic fields and build a feminist discourse, and to transform patriarchal power relations through feminist knowledge production.

The degree of political control has fluctuated over the past three decades. International sanctions after the brutal crackdown on the student movement in 1989 made the Chinese Government desperate to find an entry point to return to the global community. The United Nations (UN) Fourth World Conference on Women in 1995 presented such an opportunity. This UN-sponsored conference also ushered in a forum for nongovernmental organisations (NGOs) - a venue open to women's NGOs from all over the world. The UN conference and the NGO forum were the result of decades of operations by global feminists. Feminists within the official Chinese system swiftly seized this historic opportunity to mobilise public opinion for Chinese women's NGOs to participate in the forum, and in this way gained political legitimacy for Chinese NGOs after 1989.

The legitimate social space for women's NGOs was soon expanded by other social movements in the decade following the UN Conference on Women. It was only in this historical setting-as the slogans 'connecting the rails with the world' (与世界接轨) and 'connecting the rails with the international women's movement' (与国际妇女 运动接轨) were widely circulating in the official media-that the CSWS, an overseas Chinese feminist organisation, was able to carry out feminist activities in China. And my work to promote the development of women's and gender studies in China was possible also because of the political space for NGO activism that existed for a while following the UN Conference on Women.

\section{Self-Censorship within the Feminist Movement}

The political space in the first decade following the UN Conference on Women was nonetheless limited. I quickly learned from my collaborators in China which areas or issues were taboo. There was no need for police intervention; the organisers of feminist activities within the system knew intimately where the boundaries were drawn and took the initiative to self-censor and make sure no activities crossed the line. Having gained space for women's NGO activities, every Chinese feminist activist knew that labour movement and human rights issues were taboo. To protect the space for feminist activities, feminist NGO organisers would consciously stay within the political boundaries and not touch these 'sensitive issues'. In the initial stage of collaborations with scholars in China, I went along with this type of self-censorship out of strategic considerations as I fully understood the difficulty of opening up a space for feminist activities, as well as the various practical considerations needed to survive within the system. But, after a period of observing, I saw the limitations of such strategies and their negative effects on the feminist movement. The following passage is an excerpt from an article I wrote in 2006 reflecting on Chinese feminist NGOs in the decade after the Fourth World Conference on Women:

To critically examine Chinese feminist NGO activism, it is necessary to ask not only what has been accomplished by feminist activists but also what has been neglected or omitted. In sharp contrast to transnational feminist emphasis on multiple systems of oppression and intersectionality of gender, class, race, ethnicity, sexuality, and so on, the absence of 'class' in Chinese feminist articulation is glaring. The rapid ascendance of the analytical category 'gender' is, in a sense, at the expense of erasing the analytical category 'class' in China. Feminists in China have voraciously embraced gender exactly at the moment when the term 'class' has turned into a new political taboo ... In the post-Mao market economy, the state, with complicit help from elite intellectuals, has conveniently abandoned Marxist class analysis in the aftermath of critiquing the Maoist definition of class. Gone also were the previous socialist principles of socialist justice and equality. In their place we have witnessed the rise of neo-liberalism and stark class polarization over the past two decades. And the state has placed severe surveillance on spontaneous 
organizational activities around class issues. However, class and gender often intersect, resulting in large female populations with little resources both in urban and rural societies. In this context, the ascendance and centrality of 'gender' in the past decade functions both as a feminist tactic to promote the value of social justice against a dominant social Darwinist ideology amid rampant capitalism and a feminist evasion of sensitive issues like class ...

A focus on gender could, theoretically, include class issues as well. And feminist projects generally are already conceptually oriented towards the disadvantaged and marginalized, including laid-off women workers, migrant workers, and domestic helpers. However, without the freedom to articulate a clear critical framework that addresses multiple hierarchies and inequalities, Chinese feminists run the risk of being co-opted by the state. Their success in engaging the state via the official [Women's Federation] and their discursive legitimacy to pursue gender equality as part of full modernity have been made possible largely because most feminists consciously operate within the parameters of the current political culture ... Tactful cautiousness is sometimes hard to separate from a desire to be accepted by the official system.

Now that another decade has passed, it is clear to me that the range of regulated activities undertaken by the previous generation of feminists out of their tactful concerns has gradually become the perception of what feminism is about among many young Chinese feminists. It appears that feminist activities can focus only on fighting for women's equal rights, while challenging and criticising the male-dominated political structure, political ideology, and economic systems have nothing to do with feminism. This phenomenon is precisely the result of political taboos and the long-term consequence of Chinese feminist self-censorship. I worry that the decades-long political bondage may see practitioners accept taboos as the norm, confine their thinking to the limits of the state's permission, and lose the ability to question taboos, and the courage to challenge disciplinary mechanisms. It is absolutely necessary for every Chinese feminist to consciously analyse the effects of political control at a conceptual level and to reflexively examine manifestations of our own self-censorship so as to gain the ability to reject the dictator's mental foot-binding, which is practised on a daily basis. Among generations of Chinese feminists there have always been wise and brave warriors who soberly rejected spiritual and intellectual bondage. I have deep respect for them and, because of their existence, I always have confidence in the future of Chinese feminism.

\section{The Advantages and Disadvantages of Being a Diaspora Activist}

My teaching position at the University of Michigan allows me to be financially free of the control of the official system in China. Conducting feminist activism in China, I am far less concerned about possible punishment for breaking political taboos than are my collaborators, who worry about being able to continue making a living in China. What concerns me most is whether my actions will negatively impact on my collaborators. In the two decades prior to Xi Jinping's rise to power and the subsequent deterioration of China's political climate, Chinese universities had encouraged scholarly exchange with academic institutions abroad and my position at the University of Michigan was a plus for my academic feminist activism. Before the ascendance of the discourse of 'hostile foreign forces' (境外敌对势力), and when the official slogan 'connecting the rails with the world' still had currency, a scholar from a prestigious university in the United States with grants was welcomed, even though Chinese university administrators did not care about feminist scholarship. Deliberately breaking political taboos in the relatively 'free' academic space, I ran many seminars and workshops to introduce young faculty and graduate students in Chinese universities to femi- 
nist texts critical of global capitalism and neoliberalism, highlighting feminist analyses of multiple oppressive systems and the intersection of gender, class, race, ethnicity, sexual orientation, and other power relations. Introducing and translating feminist texts became my way of 'smuggling' critical concepts such as 'class' into Chinese academia, where a whole generation of young scholars had not encountered the Marxist term 'class' (阶级), being taught only about the Weberian concept of 'stratification' (阶层).

When proofreading translated texts by scholars in China, I had to repeatedly correct their Chinese rendition of 'class' in the original English feminist texts into 'stratification'. The erasure of 'class' as a critical concept was a material reality in a state where Chinese intellectuals were largely complicit in the statist scheme. I prepared participants in my seminars and workshops for my 'hearsays' by emphasising that my goal was to offer what they normally were unable to get in China. I advocated creating a no-taboo academic space in which to learn critical thinking and analytical tools of feminism, and to freely discuss issues related to Chinese politics and society. My goal has been to form a feminist critical discourse that challenges the dominant neoliberal and social Darwinist discourse in China and hopefully shapes the emergence of a new type of feminist subjectivity.

Aside from working in China's higher education system to promote feminist curriculum transformation, my scholarly research is also part of my feminist action. My two English monographs excavate the rich heritage of Chinese feminism. The purpose of producing these history books was to construct a genealogy of Chinese feminism so that younger generations may be inspired by their brave and intelligent feminist predecessors, learn from their insights and lessons, and carry forward their unfinished struggles. Feminist historical knowledge production also challenges mainstream history and master narratives.

Some young feminists in China intend to draw a line between academic and activist groups; I do not know into which category they would put me. I have always been in universities in the United States and China, and the institution of higher education is where I engage in feminist action. Those who try to use the term 'academic' to devalue people engaged in feminist knowledge production and the dissemination of feminist knowledge need to read some of Foucault's expositions on knowledge production to understand the close relationship between feminist knowledge production and feminist social, cultural, and political transformations. Young Chinese feminists urgently need to learn critical analytical frameworks to see through the various myths created by the dominant discourse so as not to be controlled by the ruling power.

Of course, there are also elite scholars who use feminist academic theories as a tool to climb the social ladder. For them, practising what they preach is not their concern. There are such people in all countries, let alone the Chinese intellectuals who are under the double trap of carrot and stick. But such people should not be seen as representative of scholars who have been working tirelessly in feminist academic settings and classrooms. Exactly because of feminist scholars' hard work, feminist theories and critical concepts have slowly entered Chinese universities and academic circles. Compared with my generation, many young Chinese students today have some knowledge of critical feminist concepts-way more than we had when we were young.

I would also like to emphasise that feminists are not supposed to adopt devaluing 'othering' schemes. Feminist movements worldwide always involve diverse groups of people without a centre, and with no unified leadership under an authoritative figure. The development of a movement on the margin of society depends on every practitioner respecting other people in different social positions and engaging in various practices to the best of their ability and conditioned by their environment. It is the sum of each individual's initiative and creative practice that promises to make the movement a driving force for social change. Chinese feminists who, under tight political control and surveillance, lack open channels for communication and free space for discussion and debate often have little understanding of the efforts of other feminists. Therefore, it is crucial to avoid acting 
on assumptions rather than on facts so as not to manufacture fractures in feminist communities in an already intense political environment.

My cross-cultural identity also puts me in a position of adversity. In the second decade following the UN women's conference, the political trend of the Chinese Party-State shifted from 'connecting the rails with international standards' to 'warning against hostile foreign forces'. One social movement after another was suppressed on charges of colluding with 'hostile foreign forces'. In 2017, this political stick finally officially hit feminism. The following passage is an excerpt from an official speech by the ACWF's top leader, Song Xiuyan, that year:

\begin{abstract}
At present, our Party is uniting and leading the whole Party and the people to a decisive victory over the building of a moderately prosperous society in an all-round way. Western hostile forces are stepping up their Westernisation and dividing strategy against China. They attack the Marxist theory on women and our fundamental state policy of equality between men and women, and actively sell Western 'feminism' and 'feminist supremacy'. Some under the banner of so-called 'rights protection', 'poverty alleviation', and 'charity', directly intervene in China's women's affairs in an attempt to find and open gaps in the women's field.
\end{abstract}

To me, a historian of modern China, this political stick of 'Western hostile forces' is no different from the 'class struggle' stick of the Mao era. As long as the political power struggle needs it, the opponent can be labelled a 'capitalist roader', 'party traitor', 'bourgeois academic authority', 'revisionist', 'collaborator with foreign countries', and so on. Various framings could be imposed on someone for the purpose of beating the opponent dead for fear they might threaten their power. All these schemes have nothing to do with the welfare of the people. Now, because I work at an American university and my feminist knowledge production and cultural transformation activities take place in China, I will be classified as an 'overseas hostile force'. In 2018, in a public speech in China, I specifically made a critical association between Mao Zedong's scheme of class struggle and the current discursive scheme of invoking the term 'hostile foreign forces' while revisiting the mistakes the CCP has made in history. The plain-clothes police present at my lecture reported me to the top administrator of the university. A feminist colleague commented: 'Just as they wanted to frame you as an overseas hostile force, you would criticise them publicly. Of course, they are angry.' Such ridiculous and sad situations are a reality that feminist scholars living abroad must now face.

In fact, a similar version of this phrase was first used against feminists after the crackdown on the Feminist Five in 2015. At that time, I wrote a short piece entitled 'What Is a Foreign Political Force?' to expose the insidious implications of this political discourse. The spatial position I occupy and the historical knowledge I possess allow me to openly reject the political suppression of feminism. I also call on all readers who are concerned about the development of feminism in China to expose and reject any political stigma and framing of feminism according to the conditions permitted by one's specific location. We should prevent ourselves from becoming victims of political persecution and be wary of anyone who may become a conspirator in the process of political framing. With the rapid changes in geopolitical terrain today, my diaspora identity will further complicate my transnational feminist practices, but it is all the more urgent to continue the struggle.

\section{Creating a Cyber Space for Transnational Chinese Feminist Networking}

Confronting drastically compressed political space and increased surveillance in China, a group of feminist scholars at home and abroad has created a new website, chinesefeminism.org, which provides a digital forum as well as an archive. Interested people may look for updates on Chinese feminist activities, recent feminist analyses of ongoing 
political, social, and cultural events, and academic resources that are useful to feminist academics as well as to a general readership interested in feminist scholarship and histories. The website also provides a space for feminists to articulate critical voices without self-censorship. Authors have the option to remain anonymous by using pen-names. Organising various sections for the website, Chinese feminists situated in diverse transnational locations are able to form a virtual network for feminist action as well as for supporting one another in a precarious political moment. The organisers are considering adding English versions of the major Chinese texts on the website to inform the Anglophone world of the difficult battles brave Chinese feminists are fighting in this critical historical juncture. The website illustrates vividly how Chinese feminists are not succumbing to adversity but are instead actively exploring various spaces and creating new venues to advance the feminist cause. 
This text is taken from Made in China Journal: Volume 6, Issue 2, 2021, edited by Ivan Franceschini and Nicholas Loubere, published 2021 by ANU Press, The Australian National University, Canberra, Australia.

doi.org/10.22459/MIC.06.02.2021.21 